JOANNA M. ŁUKASIK

ORCID 0000-0001-5530-5109

Uniwersytet Pedagogiczny im. Komisji Edukacji Narodowej

$w$ Krakowie

INETTA NOWOSAD

ORCID 0000-0002-3739-7844

Uniwersytet Zielonogórski

\title{
PRZYWÓDZTWO I ZAUFANIE W ŚRODOWISKU SZKOLNYM. UWAGI NA KANWIE ROZWOJU SZKOŁY
}

\begin{abstract}
Aвsтract. Łukasik Joanna M., Nowosad Inetta, Przywództwo i zaufanie w środowisku szkolnym. Uwagi na kanwie rozwoju szkoty [Leadership and Trust in the School Environment. Notes on the Background of School Development]. Studia Edukacyjne nr 52, 2019, Poznań 2019, pp. 173-189 Adam Mickiewicz University Press. ISSN 1233-6688. DOI: 10.14746/se.2019.52.12

Having the right potential as well as the desire to develop yourself, students or school is not possible in the absence of conditions that favor (self) development and development of entities and institutions. It is not just the material conditions that are extremely important; the immaterial space of school is more important, which is formed by the relations between the subjects based on fundamental human values. The subject matter discussed in the article is focused on the importance of the school development category and the entities operating in it. The text discusses selected work of researchers sensitizing to the possibilities and limitations of the development of schools that emphasize the importance of leadership and trust in school everyday life as those that significantly contribute to the improvement of schoolwork and efficiency increase. Teachers' leadership is understood here as the essence and competence leading to development and trust as a value decisive for the moral space of the school, its culture conducive to learning.
\end{abstract}

Key words: school development, trust, leadership, moral space, teacher

\section{Wprowadzenie}

Zjawisko przyrostu wiedzy zwraca uwagę na narastającą siłę i rozpiętość zmian. Warto przypomnieć, że początkowo ludzkość potrzebowała 1500 lat, 
by w XVI wieku podwoić ilość posiadanej wiedzy. Od tego czasu proces jej narastania przybierał tylko na sile. U progu XX wieku zajmował 25 lat, a pod koniec już tylko 10. Współcześnie, w pełnej dostępności do komputerów, smartfonów, tabletów i oczywiście Internetu, ilość zgromadzonej wiedzy podwaja się jeszcze szybciej. Jednak pomimo tworzącego się natłoku, wiedza utrzymuje swoją silną pozycję. Zdaniem Alvina Tofftera, zwycięży ten, kto będzie miał dostęp do informacji, umiejętność jej przetwarzania i stosowania. Wiedza stała się najważniejszą wartością współczesnej cywilizacji. Przewagę w świecie zdobywa nie ten, kto będzie umiał produkować, lecz ten, kto będzie zdolny wymyślać nowe produkty i korzystać z wiedzy. Jest to skutek uczenia się - procesu, do którego profesjonalnie przygotowani są (lub powinni być) nauczyciele.

Jack Welch alarmuje, iż „jeśli tempo zmian na zewnątrz przekracza tempo zmiany w środku - koniec jest bliski"1. Uczula to na zwrócenie baczniejszej uwagi na podejmowane zmiany w środowisku szkolnym adekwatnych, a najlepiej przewidujących zmiany $\mathrm{w}$ otoczeniu. $\mathrm{W}$ tym przypadku, planowanie rozwoju szkoły zorientowanego na poprawę uczniowskich osiągnięć nie jest mrzonką nielicznych szkół, lecz koniecznością - wyzwaniem postawionym wszystkim placówkom edukacyjnym, którym w swojej pracy muszą sprostać nauczyciele. Oznacza to konieczność modyfikowania wpływów wewnątrzszkolnych z uwzględnianiem tych zewnętrznych, które nie są obojętne dla szkolnego życia i wyznaczają kierunek zmian.

Oczywiście, poprawa uczniowskich osiągnięć uwzględniająca ich rozwój nie jest możliwa, jeśli nauczyciele, jako profesjonaliści, odpowiedzialni za podejmowane działania, sami nie dbają o własny rozwój oraz nie posiadają odpowiedniej wiedzy, cech i predyspozycji osobowych oraz umiejętności. Warto jednak zauważyć, że samo posiadanie odpowiedniego potencjału, a także pragnienie rozwoju siebie, uczniów, czy szkoły nie jest możliwe w przypadku braku warunków, które sprzyjają (samo)rozwojowi i rozwojowi podmiotów oraz instytucji. Nie chodzi wyłącznie o warunki materialne, które są niezwykle ważne. Jednakże, ważniejsza jest niematerialna przestrzeń szkoły, którą tworzą relacje pomiędzy podmiotami oparte na naczelnych, ogólnoludzkich wartościach. Wszelkie destrukcyjne czynniki zakłócające relacje pomiędzy podmiotami utrudniają rozwój, wprowadzają aksjologiczny chaos i niepewność miejsca. Uwagi tu poczynione unaoczniają konieczność zwrócenia baczniejszej uwagi na kategorię rozwoju szkoły, która w zaakceptowanym przez społeczeństwo porządku demokratycznym może być opisana przez pryzmat koncepcji uczącej się szkoły, tworzącej przestrzeń do praktykowania rozwoju przez nauczycieli.

${ }^{1} \mathrm{~J}$. Welch, za: I. Yashin-Shaw, Leading in the Innovation Age: Unleash knowledge, talent and experience to create an innovative workplace, BookPod, 2016. 
W prezentowanym artykule przedmiotem dyskusji uczyniono szkołę, zarówno jako miejsce jej rozwoju (rozwoju organizacyjnego), jak i podmiotów w niej funkcjonujących. Ze względu na ramy określone wymaganiami dla artykułów naukowych przybliżono wybrane prace badaczy uwrażliwiających na możliwości i ograniczenia rozwoju szkoły eksponujących rangę przywództwa i zaufania w szkolnej codzienności jako tych, które w istotnym stopniu przyczyniają się do poprawy pracy szkoły i wzrostu efektywności. Przywództwo nauczycieli jest tu rozumiane jako istotna kompetencja wiodąca do rozwoju, zaś zaufanie - jako wartość decydująca o przestrzeni moralnej szkoły, jej kulturze sprzyjającej uczeniu się.

\section{Rozwój szkoły i kultura szkoły}

Rozwój szkoły można określić jako specyficzne działania (interwencje) wywierane na szkoły z zewnątrz lub/i podejmowane przez podmioty reprezentujące ją wewnątrz, zorientowane na wspieranie jakości i efektywności procesów wewnątrzszkolnych służących rozwojowi uczniów i wzrost ich osiągnięć $w$ celu zapewnienia trwałej poprawy². Proces rozwoju szkoły będzie zatem dotyczyć zewnętrznych oraz wewnętrznych działań celowych i co ważne - zorientowanych na wywieranie trwałego wpływu na poprawę uczniowskich osiągnięć w codziennych sytuacjach szkolnych ${ }^{3}$. Na znaczeniu zyskują wówczas grupy czynników zewnętrznych - kontekstowych, jak i wewnętrznych - oddziałujących w szkole jako specyficznej jednostce. Jednak badacze podkreślają, iż takie wskazania należy traktować z dużą granicą błędu. Bowiem, choć udało się zdefiniować i opisać szereg czynników na różnych poziomach systemów edukacyjnych, które w większości krajów są powiązane $\mathrm{z}$ efektywną poprawą funkcjonowania szkół (przynajmniej w pewien sposób), to jednak trudno wyodrębnić czynniki, które działałyby w dokładnie taki sam sposób we wszystkich krajach ${ }^{4}$. Nawet jeśli wybrane czynniki powielały się, to ich wpływ różnił się w poszczególnych krajach od (bardzo) pozytywnego do (bardzo) negatywnego. Ponadto, nawet w jednym

\footnotetext{
${ }^{2}$ Por. I. Nowosad I., Uwarunkowania rozwoju szkoty, [w:] Edukacyjne konteksty wspótczesności z myślą o przyszłości, red. J. Madalińska-Michalak, N.G. Pikuła, Kraków 2018.

${ }_{3}^{3}$ I. Nowosad, Perspektywy rozwoju szkoty. Szkice z teorii szkoty, Warszawa 2003.

${ }^{4}$ G.J. Reezigt, B.P.M. Creemers (red.), A framework for effective school improvement. Final report of the ESI project, Groningen 2001; D. Hopkins i in., School and System Improvement, State of the Art Review Keynote presentation prepared for the 24th International Congress of School Effectiveness and School Improvement, Limassol 2010, Cyprus, 6th January 2011, w: https://www.icsei.net/ icsei2011/State_of_the_art/State_of_the_art_Session_C.pdf [dostęp: 2017.12.10]; C. Belleia i in., School improvement trajectories: an empirical typology, School Effectiveness and School Improvement, 2015: https://globaled.gse.harvard.edu/files/geii/files/bellei_et_al_-school_improvement_trajectories.pdf [dostęp: 2017.12.10].
} 
kraju mogą wystąpić istotne różnice pomiędzy szkołami. Bowiem, poprawa funkcjonowania szkół może być odmiennym procesem w placówkach, które odniosły sukces oraz w szkołach, które dopiero na ten sukces liczą ${ }^{5}$.

Michael Fullan w opisie rozwoju szkoły zwraca uwagę na wysoką świadomość społeczności międzynarodowej, iż lepsza edukacja jest kluczem do społecznej i globalnej produktywności oraz dobrobytu indywidualnego i społecznego ${ }^{6}$. Wzmaga to tylko działania zorientowane na troskę o jakość edukacji i możliwość poprawy w szerokiej skali, a nie tylko incydentalnych sukcesów. Wówczas skuteczność i efektywność poprawy szkoły (szkół) jako trwały proces, na stałe wpisany $\mathrm{w}$ działalność i misję szkoły, przejawia się $\mathrm{w}$ codziennych sytuacjach, często niedostrzeganych z perspektywy globalnych efektów. Na znaczeniu zyskuje również zaangażowanie społeczności szkolnej w proces inicjowania celowych zmian i tym samym zwiększenie odpowiedzialności oraz wspólnej kontroli nad treścią, jak i tempem ich wprowadzania. Można przyjąć, że rozwój szkoły w szkolnej codzienności lub bardziej codzienność rozwoju szkoły ,jest procesem rozpoznawania nowych potrzeb, uczenia się poprzez doświadczenie, tworzenia nowej praktyki i nabywania biegłości we wspólnym działaniu"7. Sprawia, że społeczność szkoły rozpatrując stawiane przed nią wymagania czyni to w świetle własnej wizji i misji, kreując w ten sposób swoją przyszłość. Podejście takie eksponuje znaczenie bezpośredniego zaangażowania wszystkich pracowników szkoły i uczniów w określanie potrzeb, ustanawianie celów programu rozwoju placówki, jako warunku samoistnej i autentycznej odnowy, ale także, i to coraz dobitniej, zmiany wartości oraz przekonań społeczności szkolnej rozumiane jako przekształcanie kultury szkoły.

Długa tradycja badań edukacyjnych wskazuje na kulturę szkoły jako kluczową zmienną w zrozumieniu zmiany i doskonalenia pracy szkoły. Już w latach 30. XX wieku Willard Waller sugerował, że typowe szkolne kultury ograniczają wysiłki na rzecz innowacji ${ }^{8}$. Do podobnego wniosku doszedł Seymour Sarason pięćdziesiąt lat później, udowodniając, że szkoły nie mogą się znacząco zmienić, chyba że zostaną zakwestionowane podstawowe ele-

${ }^{5}$ L. Stoll, D. Fink, The cruising school: The unidentified ineffective school, [w:] No quick fixes: Perspectives on schools in difficulty, red. L. Stoll, K. Myers, London - Washington 1998, s. 189-206.

${ }^{6}$ M. Fullan, Przedmowa w: Jak najlepiej doskonalone systemy szkolne na świecie stają się jeszcze lepsze, s. 11, w: M. Barber, M. Mourshed, How the World's Best-Performing School Systems Come Out on Top, McKinsey and Co, 2007: ww.mckinsey.com/clientservice/socialsector/resources/ pdf/

7 B.D. Gołębniak, Szkoła wspomagająca a rozwój, [w:] Pedagogika. Podręcznik akademicki, tom 2, red. Z. Kwieciński, B. Śliwerski, Warszawa 2003, s. 98-122; A. Hildebrandt, Koncepcja rozwoju organizacyjnego szkoły Pera Dalina, [w:] Szkice z teorii i praktyki zmiany oświatowej, red. E. Potulicka, Poznań 2001, s. 74.

${ }^{8}$ W. Waller, The Sociology of Teaching, New York 1932. 
menty ich kultury. Proces rozwoju szkoły w codziennych sytuacjach zwraca wówczas uwagę na to "jak my tutaj to robimy”, czyli na trudną do określenia przestrzeń kultury szkoły. Każda próba udoskonalenia lub poprawy pracy szkoły, która ją pomija, będzie oznaczać bezproduktywną działalność, która choć wprowadza zmiany, to jednak takie, które nie przyczyniają się do wzrostu uczniowskich osiągnięć. Społeczność szkoły może doznawać frustracji, kiedy podejmuje wysiłki, które w zasadzie nic istotnego nie wnoszą ${ }^{9}$. Michael Fullan w swoich pracach zwraca uwagę, że próby podejmowania zmian i doskonalenia szkół w dużej mierze koncentrują się na narzucaniu nowych zadań i praktyk - czyli na restrukturyzacji - zamiast na ich przekwalifikowaniu, czyniąc ze szkół miejsca stymulujące nauczycieli i wspierające ich w dokonywaniu znaczących zmian od wewnątrz. Skupia to uwagę na specyfice zmian w szkołach i na tym, że nie każda zmiana jest dla szkoły ważna, czy choćby nawet potrzebna.

Rozwojowi szkoły, aby skutki zmiany były trwałe, musi być poświęcony dłuższy czas i wypracowane nowe podejście do postrzegania zmiany i jej odczuwania. Wówczas proces rozwoju szkoły Fullan utożsamia z procesem rekulturacji, który przewartościowuje najgłębsze poziomy uznawanych wzorców i wartości oraz zmienia perspektywę z zewnętrznej (wyznaczane terminy) na wewnętrzną, we wszystkich obszarach: kultury szkoły oraz struktury i czasu jako czynników wspierających ${ }^{10}$.

Wprowadzanie zmian wymaga czasu i nie jest to zaskakujące. W procesie rekulturacji istotne są wewnętrzne postawy wobec czasu, czyli subiektywne miary orientacji temporalnej. Kurt Lewin opisał czas jako jeden z najważniejszych wymiarów indywidualnego i społecznego funkcjonowania człowieka ułatwiający poznanie ${ }^{11}$. Jego percepcja ma dla człowieka charakter regulacyjny i może wspierać proces rekulturacji. Podobnie restrukturyzacja, która jako cel sam w sobie nie wnosi do szkolnej codzienności zmian $\mathrm{w}$ trwałej poprawie oraz sposobie profesjonalnego funkcjonowania nauczycieli $^{12}$. Fullan zauważa, że mamy tendencję do reagowania reorganizacją na dowolną sytuację i jest to wspaniała metoda na stworzenie iluzji postępu. Badacze wykazali również, że pewien stopień restrukturyzacji może być ko-

${ }^{9}$ M. Fullan, Indelible leadership: Always leave them learning, Thousand Oaks 2016; M. Fullan, A. Hargreaves, Bringing the profession back in: Call to action, Oxford 2016; M. Fullan, J. Quinn, Coherence: The right drivers in action for schools, districts, and systems, Thousand Oaks 2016.

${ }^{10}$ M. Fullan, Leading in a culture of change, San Francisco 2001.

${ }^{11}$ Warto pamiętać, że Kurt Lewin opracował fundamenty pod współczesną psychologię temporalną. Por. K. Lewin, Field theory in social science; selected theoretical papers, New York 1951.

${ }_{12}$ M. Berends, A Description of Restructuring in Nationally Nominated Schools. Paper presented at the Annual Meeting of the American Educational Research Association, San Francisco 1992, za: M. Fullan, Change Forces: Probing the Depths of Educational Reform, London 1993. 
nieczny, zanim dojdzie do rekulturacji, ale jest to możliwe tylko wtedy, gdy pracownicy szkoły sami opracują nowe struktury i nie zostaną one zaordynowane $\mathrm{z}$ zewnątrz ${ }^{13}$.

Fullan podkreśla, że przekształcanie (kształtowanie) kultury szkoły - rozumiane jako zmiana podejścia do wykonywanych prac - jest najważniejszym celem i nazywa ten proces właśnie "rekulturacją"14. Rekulturacja, restrukturacja i reorientacja czasowa łącznie pozwalają na wgląd $w$ to, czy szkoły pomyślnie lub bez powodzenia poradziły sobie z procesem zmian. Oczywiście, najważniejsza jest zmiana kultury, ale pozostałe elementy mają charakter wspierający - jak zmiany struktur lub konieczny - jak czas potrzebny na przeprowadzenie zmiany. Steve Gruenert stwierdził, że jeśli coś się nie zmieni, to dlatego, że istniejąca kultura na to nie pozwoliła ${ }^{15}$. Na poziomie szkoły wskazuje to na fakt, że liderzy szkolni mają trudności ze zrozumieniem i dostosowaniem się do różnych norm i zachowań w całej organizacji. Z drugiej strony, ci, którzy są świadomi rangi kultury mają z nią silny związek. Są bardziej wrażliwi i zdolni do interakcji z innymi wartościami i wzorcami (innymi typami kultury), elastyczni i jednocześnie skuteczni.

Kultura szkoły tworzy środowisko psychospołeczne, które ma głęboki wpływ na całą społeczność szkoły: nauczycieli, administrację i uczniów. Leslie Kaplan przypisuje jej kluczowe znaczenie w procesie zmiany i uważa, że kultura szkoły kształtuje jej organizację ${ }^{16}$. Poprzez wzmocnienie wśród pracowników wspólnej identyfikacji na znaczenie codziennych aspektów szkolnego życia, kultura pełni w szkole różne funkcje, których świadomość i uwzględnienie ma istotne znaczenie w procesie zmiany - jest niezbędna, jeśli chcemy osiągnąć zrozumienie udanych zmian w szkołach ${ }^{17}$.

- Buduje poczucie tożsamości - jasno zdefiniowane i wspólne postrzeganie wartości wspiera proces budowania tożsamości jednostek, stwarza członkom organizacji poczucie kim są i wzmacnia ich odrębność jako grupy.

- Wzmacnia zaangażowanie - jako sposób myślenia o innych i wyjście poza siebie. Sprzyja wzrostowi aktywności włączania się w coś większego niż indywidualny, własny interes.

- Kształtuje standardy zachowania - kultura określa język i działania pracowników zapewniając spójność behawioralną, określa normy i niepisa-

${ }^{13}$ L.M. Hannay, J.A. Ross, Initiating Secondary School Reform: The Dynamic Relationship between Restructuring, Reculturing, and Retiming, Educational Administration Quarterly, 1997, 33(1), s. 576-603.

${ }^{14}$ M. Fullan, Leading in a culture.

15 S. Gruenert, Shaping a new school culture, Contemporary Education, 2000, 71(2), s. 14-18.

${ }^{16}$ L.S. Kaplan, W.A. Owings, Culture Re-Boot: Reinvigorating School Culture to Improve Student Outcomes, 2013, (e-book 2014).

${ }_{17}$ P. Angelides, M. Ainscow, Making sense of the role of culture in school improvement, School Effectiveness and School Improvement, 2000, 11(2), s. 145-163. 
ne zasady, w tym także to, co pracownicy powinni mówić i robić w danych sytuacjach.

- Zapewnia kontrolę społeczną - wspólne wartości kulturowe, wierzenia i praktyki zachowują się $\mathrm{w}$ nieformalnych regułach (zinstytucjonalizowane normy), które zwiększają stabilność systemu społecznego oraz wzmacniają i kształtują kulturę w cyklu powtarzalnym.

\section{Znaczenie przywództwa nauczycieli w rozwoju szkoły}

Kategoria przywództwa w szkolnej codzienności jest jednoznacznie powiązana z wywołaniem w szkole dążenia do zapewnienia środowiska sprzyjającego poprawie uczniowskich osiągnięć i najczęściej odnosi się do przeprowadzenia procesu zmiany (kształtowania) kultury szkoły ${ }^{18}$. Można nawet uznać, że analizy dotyczące przywództwa stanowią jeden z najintensywniej rozwijających się obszarów badawczych w dziedzinie rozwoju szkoły (School Effectiveness and School Improvement). Na podstawie prowadzonych badań opracowano lub zaadaptowano z teorii organizacji i zarządzania wiele modeli, często bardzo do siebie podobnych lub pokrywających się w opisie. Modele te powstały w odpowiedzi na wyzwania stojące przed szkołą (edukacją), interpretowane na kanwie różnych teorii przywództwa. Dokonując oglądu bogatej już na tym polu literatury ${ }^{19}$, można przyjąć, że szczególne zainteresowanie towarzyszy tym modelom, które odsuwają uwagę od konserwatywnego zarządzania szkołą na rzecz tworzenia struktur innowacyjnych i elastycznych. Jest to przykład rosnącego nacisku na trwałą poprawę szkoły, a dokładnie konieczność wykorzystania potencjału szkolnej społeczności w poprawie uczniowskich osiągnięć i stworzenia warunków do rozwoju, choć nie tylko. Współcześnie coraz silniej widoczna jest tendencja do włączania innych agend w środowisku lokalnym szkoły, jak i na różnych szczeblach zarządzania szkolnictwem w budowaniu sieci przywództwa edukacyjnego - osób zaangażowanych w proces poprawy rozumiany jako uczenie się i tworzenie środowiska edukacyjnego wysokiej jakości.

${ }^{18}$ T. Bush, Theories of educational leadership, s. 15.

${ }^{19}$ Interesujące spostrzeżenie dotyczące literatury z zakresu problematyki kształcenia i doskonalenia zawodowego dyrektorów zostało ukazane przez Zbyszko Melosika, który analizując literaturę przedmiotu wykazał, że „za wyjątkiem Stanów Zjednoczonych jest ona fragmentaryczna i uboga; nie ma zwartych, spójnych opracowań w tym zakresie. Raport w dużej mierze opiera się na analizie anglojęzycznych dokumentów dotyczących zagadnień kształcenia i dokształcania dyrektorów w USA i wybranych krajach Unii Europejskiej", cyt. za: Z. Melosik, Systemy ksztatcenia i doskonalenia kadry kierowniczej w krajach Unii Europejskiej i Stanach Zjednoczonych, Warszawa 2014, s. 17. 
W raporcie opublikowanym w 2006 roku Seven Strong Claims about Successful School Leadership, przywództwo jest na drugim miejscu, zaraz po nauczaniu w klasie w zakresie jego wpływu na procesy uczenia się uczniów. Wykazano, że „działa jak katalizator" w osiąganiu przez szkołę korzystnych efektów ${ }^{20}$. W raporcie rozróżnia się także wpływ przywództwa dyrektorów (zazwyczaj jest to 5-7\%) i całkowitego przywództwa (27\%). Wyniki badań Viviane Robinson ukazują, że charakter roli lidera znacząco wpływa na efekty uczenia się. Bezpośrednie zaangażowanie lidera w planowanie programu nauczania i rozwój zawodowy wiąże się z umiarkowanymi lub dużymi efektami. Sugeruje to, że liderzy im bliżsi są podstawowej działalności nauczania i uczenia się, tym bardziej prawdopodobne jest, że będą mieć wpływ na uczniów ${ }^{21}$. Wnioski badaczy były jednoznaczne: „nie ma ani jednego udokumentowanego przypadku, w którym w sytuacji braku utalentowanego kierownictwa, szkoła z powodzeniem zmieniła trajektorię osiągnięć uczniów"22. Odkrycia badaczy wskazują na wymierne efekty przywództwa i budzą zainteresowanie nowymi modelami, podbudowanymi lepiej nie tylko teoretycznie, lecz przede wszystkim empirycznie. Odkrycia te dostarczają podstaw dla aktualnego zainteresowania modelami przywództwa "osadzonego" bliżej ucznia i kierują uwagę na przywództwo nauczycieli, przywództwa edukacyjnego, które sprzyjają harmonijnemu budowaniu wspólnoty.

Cechą konstytutywną przywództwa jest wizja. Przywódca ma być wyznacznikiem kontekstu, projektantem doświadczenia edukacyjnego - nie autorytetem w kwestii rozwiązań. Dyrektor szkoły zmieniając swoje podejście do strategii, zmienia sposób, w jaki działa cała organizacja. Kiedy społeczność szkoły staje się tego świadoma, odkrywa, że albo może pomóc w stworzeniu rozwiązania lub wręcz ma gotową odpowiedź na zaistniały problem - wtedy zmiana następuje niezwykle szybko, a uczenie się przyspiesza i postępuje niezwykle twórczo. Wówczas w rozwiązaniu jest do dyspozycji o wiele więcej pomysłów, niż w przypadku stosowania starych strategii - narzuconych przez zarządzających systemem oświaty.

Przywództwo w profesjonalnym środowisku szkolnym nie jest przypisane wyłącznie dyrektorowi czy jego zastępcom. Pojawia się paradygmat przywództwa zespołowego, lepiej i skuteczniej reagującego na zmieniające się warunki szkoły i jej otoczenia, uwzględniającego procesy demokratyczne i interakcje, a nie tradycyjne autokratyczne struktury organizacyjne. Można to odczytać jako możliwość sprawowania przywództwa poprzez wspólne podejmowanie decyzji i współpracę, w miarę jak nauczyciele angażują się

\footnotetext{
${ }^{20}$ K. Leithwood i in., Seven Strong Claims about Successful School Leadership, London 2006.

${ }^{21}$ V. Robinson, School Leadership and Student Outcomes: Identifying What Works and Why, Winmalee 2007, s. 20-21.

${ }^{22}$ K. Leithwood i in., Seven Strong Claims, s. 5.
} 
w określanie własnych potrzeb zawodowych w zakresie edukacji i ich związku z misją szkoły. W sytuacji wielu liderów w środowisku szkolnym wyłania się również potrzeba zrównoważenia siły przywódczej pomiędzy nauczycielami jako liderami (przywództwo edukacyjne lub przywództwo nauczycieli) a dyrektorem szkoły jako głównym zarządzającym organizacją szkoły (koordynacja, administracja). Wydaje się to możliwe do określenia przez samą szkołę, która odnajdzie dynamiczną równowagę w przywództwie zapewniającym trwałą poprawę (rozwój) szkoły.

Złożoność sytuacji szkolnych zwraca uwagę badaczy na skuteczność tych liderów, którzy opanowali wszystkie style zarządzania i umieją je właściwie oraz zamiennie stosować. Istnieje bowiem konieczność posiadania zróżnicowanych strategii dla rozbieżnych sytuacji. Z tej perspektywy generalizowanie badań nad sukcesem przywództwa jest wysoce utrudnione. Jednakże, rozwijanie głębszego wyczucia, czy mówiąc wprost - uczenia się procesu zmian poprzez gromadzenie spostrzeżeń i mądrości wynikającej z różnych sytuacji nabytych w czasie wydaje się najbardziej praktyczną konkluzją wskazywaną przez badaczy ${ }^{23}$. Uczenie się jest wówczas powolnym procesem rozpoznawania, który wcale nie musi oznaczać, że trwa długo. Jest to raczej podejście, które może zostać przyswojone i wprowadzone do codziennej praktyki. Skuteczni liderzy mają świadomość czasu potrzebnego na wypracowanie jasnego obrazu (wyjaśnienie) sytuacji. Fullan zwraca również uwagę, że najbardziej skuteczni przywódcy nie mają najwyższej inteligencji w sensie IQ, ale są tymi, których cechuje wybitna inteligencja emocjonalna. Zwraca przy tej okazji uwagę na pięć najważniejszych cech wyróżniających kompetencje moralne:

- samoświadomość (rozpoznanie stanu samopoczucia, preferencji, zasobów i intuicji);

- umiejętność samoregulacji (zarządzanie wewnętrznymi stanami, impulsami, zasobami);

- motywacja (tendencje emocjonalne, które prowadzą lub ułatwiają osiągnięcie celu);

- empatia (świadomość uczuć, potrzeb i obaw innych osób);

- umiejętności społeczne (biegłość w wywoływaniu pożądanych reakcji $\mathrm{u}$ innych) ${ }^{24}$.

Inną ważną kwestią przypisywaną przez Fullana silnym instytucjom jest posiadanie wielu liderów na wszystkich poziomach jej funkcjonowania i rozwój przywództwa w innych placówkach oraz agencjach przez współpracę. Choć równie ważny w zapewnieniu trwałego rozwoju szkoły jest rozwój ta2013.

${ }^{23}$ H. Červinková, B.D. Gołębniak (red.), Pedagogika i antropologia zaangażowane, Wrocław

${ }^{24}$ M. Fullan, Leading in a culture. 
kich przywódców, którzy będą mogli kontynuować przemianę szkoły, nawet po swoim odejściu ${ }^{25}$.

Ranga i znaczenie przywództwa tkwi, chyba najsilniej, w posiadaniu wizji, która zapewnia partycypowanie przyszłości i rozwój. Uczenie się i współpraca stanowi drogę jej zapewnienia. Jednakże, taki model $w$ środowisku szkolnym, który uwzględnia ich łączność jest nadal rzadkością, nawet w państwach o długiej tradycji demokratyzacji oświaty ${ }^{26}$. Typ przywództwa, który będzie wspierać $\mathrm{i}$ obejmować wskazane procesy wydaje się $\mathrm{w}$ czasach intensywnie zachodzących zmian najbardziej pożądany ${ }^{27}$.

\section{Zaufanie jako podstawowa wartość kultury szkoły i przywództwa nauczycieli}

Z perspektywy prowadzonych rozważań niezwykle istotne jest zwrócenie uwagi na wartość, bez której nie jest możliwe przywództwo nauczycieli, ani rozwój szkoły, czy istnienie pozytywnej sprzyjającej rozwojowi szkoły odpowiedniej kultury. Wartością tą jest zaufanie. Bez niej nie ma sprzyjających warunków do budowania pozytywnej przestrzeni kultury szkoły. Jakakolwiek próba udoskonalenia czy poprawy pracy szkoły (osiągnięć uczniów, nauczycieli) będzie jedynie pozorną, chwilową ułudą, która choć wprowadza zmiany, nie przekłada się na efekty. Zatem, żeby nastąpił rozwój szkoły, a jego skutki były trwałe i wynikały z identyfikacji podmiotów szkoły z rzeczywistym, osobistym rozwojem, potrzeba czasu oraz osób żyjących wartościami, budujących zaufanie, a w dalszej konsekwencji dbających o rozwój szkoły poprzez dobre przywództwo. Dobre przywództwo nie zaistnieje w szkole, której kultura ma charakter destrukcyjny, bazuje na interesach poszczególnych grup lub osób (i ogranicza się do bezwzględnego sukcesu wynikającego wyłącznie z interesu osobistego jednostki lub grupy), bez uwzględniania potrzeb, potencjału i tym podobnych wszystkich podmiotów.

Punktem wyjścia do wprowadzania zmian zorientowanych na poprawę pracy szkoły jest zatem budowanie zaufania. Zdaniem Piotra Sztompki, „Zaufanie jest zakładem podejmowanym na temat niepewnych, przyszłych działań ludzi" 28 . Podobnie twierdzi James S. Coleman ${ }^{29}$. Badacze ci zauważają, że zaufanie jest pewnego typu zakładem, jakiego dokonują „,racjonalne

\footnotetext{
${ }^{25}$ Tamże.

${ }^{26}$ Por. Z. Melosik, Systemy kształcenia i doskonalenia kadry kierowniczej.

27 C. Rhodes, M. Brundrett, Leadership development and school improvement, Educational Review, 2009, 61(4), s. 361-374.

${ }_{28}$ P. Sztompka, Zaufanie. Fundament społeczeństwa, Kraków 2007, s. 69-70; tenże, Kapitał spoteczny. Teoria przestrzeni międzyludzkiej, Kraków 2016, s. 157.

${ }^{29}$ J. Coleman, Foundations of Social Theory, Cambridge - MA - London 1990, s. 91-118.
} 
jednostki, starając się rozpoznać i przewidzieć niepewne działania innych ludzi" ${ }^{30}$. Ten zakład bazuje na przekonaniu, że inna jednostka w swoich działaniach weźmie pod uwagę nasz interes. Inaczej mówiąc, zaufanie jest oczekiwaniem wobec innych, unaoczniającym się w tym, że inni zachowają dobrą wolę oraz honorują swoje zobowiązania i unikają krzywdzenia innych $^{31}$. Ufać można zatem na podstawie przekonania, że „inni ludzie działają w sposób przewidywalny, rzetelny, nieegoistyczny i przemyślany" ${ }^{\prime 2}$, nie działając na naszą szkodę. Podstawą zaufania są więc pozytywne intencje innego podmiotu, przejawiające się $\mathrm{w}$ regularnych, uczciwych, pozostających $\mathrm{w}$ zgodzie $\mathrm{z}$ normami i nastawionych na współpracę zachowaniach innych ludzi ${ }^{33}$. Można zatem powiedzieć, że zaufanie istnieje wówczas, "gdy przekonanie, iż inne osoby (firmy, instytucje, towary) są godne zaufania i będą spełniać nasze oczekiwania, staje się przesłanką ufnego wobec nich postępowania" ${ }^{34}$. Zaufanie jest więc możliwe wtedy, gdy człowiek jest przekonany o czyjejś wiarygodności, etycznym postępowaniu, uczciwości, prawdomówności, pomocności i empatii. Oczywiście, sam kieruje się takimi zasadami i według nich postępuje. Ponadto, zaufanie może zaistnieć wówczas, kiedy osoby postępują fair, są pomocne, odpowiedzialne, dbają o wspólne interesy ${ }^{35}$. Idąc tym tokiem myślenia o zaufaniu, można uznać, że aby mogło zaistnieć, niezbędne są określone warunki, będące również podstawą budowania kultury szkoły i dążenia do jej rozwoju poprzez przywództwo. Wśród warunków zaufania Sztompka wymienia: a) spójność normatywną; b) trwałość porządku społecznego; c) przejrzystość organizacji społecznej; d) familiarność (swojskość); e) odpowiedzialność za innych ludzi; f) charakter sieci relacji społecznych w jakie wchodzi jednostka (pozytywne stosunki społeczne).

Budowanie zaufania $\mathrm{i}$ jego urzeczywistnienie w relacjach międzyludzkich $w$ instytucji jaką jest szkoła zachodzi wówczas, kiedy zaistnieją trzy „filary”, na których zaufanie może się oprzeć: osobowość, racjonalna kalkulacja i kultura ${ }^{36}$.

Osobowość w tym ujęciu rozumiana jest jako psychologiczna skłonność do przejawiania zaufania lub skłonność do bycia podejrzliwym wobec innych (brak zaufania). Racjonalna kalkulacja to, zdaniem Sztompki, dążenie do

\footnotetext{
${ }^{30}$ T. Szlendak, Zaufanie, [w:] Fundamenty dobrego społeczeństwa. Wartości, red. M. Bogunia-Borowska, Kraków 2015, s. 332.

${ }^{31}$ T. Yamagishi, M. Yamagishi, Trust and commitment in the United States and Japan, Motivation and Emotion, 1994, 18, 2, s. 129-166.

32 T. Szlendak, Zaufanie, s. 333.

33 Tamże.

34 P. Sztompka, Kapitał społeczny, s. 157.

35 Por. tamże, s. 158 i n.

${ }^{36}$ Tamże, s. 158-166.
} 
wiarygodności (wzbudzanie wiarygodności, bycie wiarygodnym) poprzez: wygląd zewnętrzny; język ciała; zachowanie; odpowiednio zorganizowane otoczenie, w którym zachowanie występuje; cechy kontekstu. Autor zauważa, że może zdarzyć się tak, że dążenie do wiarygodności stanowi element manipulacji, jest wyuczone w celu wzbudzenia zaufania i wykorzystania tego dla własnych interesów. Trzeci filar zaufania to kultura zaufania. Uwidacznia się ona w takich relacjach i specyficznych cechach, jak:

a) obdarzanie zaufaniem spotykające się powszechnie z pozytywną reakcją partnerów realizujących związanych z zaufaniem oczekiwania;

b) gęstość i zażyłość relacji;

c) wysoki poziom współzależności i skłonności do kooperacji;

d) system regul, to jest: ufać innym, nawet nieznajomym, zakładając, że są wiarygodni dopóki okaże się, że tak nie jest; traktować poważnie zaufanie okazane przez innych i spełniać oczekiwania, dopóki nie okaże się, że zaufanie było pozorowane;

e) pobudzanie postaw prospołecznych, towarzyskość, współuczestniczenie w stowarzyszeniach;

f) wzbogacanie sieci więzi międzyludzkich, zwiększanie pola interakcji, pozwalanie na nawiązywanie bliskich kontaktów;

g) wpływ na poczucie tożsamości;

h) swobodny przepływ informacji, pozytywna komunikacja wzmacniająca współpracę ${ }^{37}$.

Zaufanie z perspektywy rozwoju szkoły jest fundamentem stabilności relacji społecznych. Kultura zaufania zaś to:

po pierwsze, efekt pewnej tradycji historycznej, po drugie możliwości strukturalnych (na przykład spójności norm, stabilności porządku społecznego czy odpowiedzialności instytucji), po trzecie zaś, nastrojów (aktywizmu chociażby, optymizmu czy orientacji na przyszłość jednostek) i cech społecznych (takich jak zamożność, wykształcenie, sieć kontaktów społecznych czy wierzenia religijne) ${ }^{38}$.

Zatem, charakter kultury decyduje o ufności bądź braku zaufania, zaś jednostkowe doświadczenia mogą modyfikować uprzednio nabytą ufność lub nieufność. Jednakże, bez zaufania nie jest możliwy rozwój szkoły. Szczególnie jeśli brak zaufania dotyczy podmiotów odpowiedzialnych za rozwój, a więc nauczycieli. Niestety, liczne badania prowadzone wśród zespołów nauczycielskich nie są optymistyczne dla budowania kultury zaufania. Z badań Mirosławy Nowak-Dziemianowicz ${ }^{39}$ wynika, że nauczyciele nie współpracu-

\footnotetext{
${ }^{37}$ Tamże, s. 161-166.

38 T. Szlendak, Zaufanie, s. 343-344; por. P. Sztompka, Zaufanie, s. 292.

${ }^{39}$ M. Nowak-Dziemianowicz, Oblicza nauczyciela. Oblicza szkoty, Torun 2001, s. 40.
} 
ją i nie współdziałają ze sobą w miejscu pracy, natomiast przeżywają liczne obawy, że otwarcie się na innych, odkrycie swoich atutów, pomysłów może zakończyć się nawet utratą pracy. Podobnie brak zaufania jest przyczyną licznych konfliktów w gronie nauczycieli ${ }^{40}$, a także negatywnych relacji zawodowych. Z badań przeprowadzonych przeze Joannę M. Łukasik wynika ${ }^{41}$, iż większość nauczycieli utrzymuje stosunki koleżeńskie z kilkoma osobami w pracy $(74,45 \%)$, zaś nieliczni są mili dla siebie i służą pomocą w różnych sytuacjach tego wymagających (62,78\%). Podobne wyniki badań uzyskała Beata Jakimiuk $^{42}$. Z badań tej Autorki wynika, że ogólnie nauczyciele podkreślają dobre relacje $\mathrm{w}$ gronie, nieco gorzej oceniają relacje z przełożonymi. Jednakże, zagłębienie się w te relacje i określenie ich przez pryzmat takich wskaźników, jak: możliwość otrzymania pomocy i wsparcia od współpracowników, docenianie przez innych, czy posiadanie zaufanych przyjaciół bardzo zmieniają obraz z pozoru dobrych relacji. Dwa ostatnie wymienione wskaźniki otrzymały najniższą rangę wśród badanych nauczycieli o różnym stażu pracy, pracujących w różnych typach szkół. Najniższy poziom zaufania do przyjaciół w miejscu pracy (czyli brak przyjaciół i brak zaufania) wykazali nauczyciele ze stażem do 25 lat pracy.

Zbliżone wyniki badań dotyczące zaufania w grupie nauczycieli otrzymała J.M. Łukasik ${ }^{43}$. Z badań nad wspólnotami pokoju nauczycielskiego i przestrzeni moralnej w miejscu pracy nauczycieli wynika, że nie ufają sobie w większości obszarów funkcjonowania zawodowego, nie mają dobrych relacji interpersonalnych, zaś jeśli już ufają innym, to najczęściej odnosi się to do działań organizacyjno-porządkowych w miejscu pracy. Wynika to między innymi z negatywnej rywalizacji, przywłaszczania pomysłów innych, bezwzględnego dążenia do własnego sukcesu, uznania władz kosztem innych, a nawet celowym krzywdzeniu innych (np. obgadywanie, plotkowanie, publiczne umniejszanie wartości i in.). Podobne zjawiska zauważył Jacek Py-

${ }^{40}$ Por. J.M. Łukasik, W stronę nauczycielskiej „wspólnoty wrażliwej” na rozwój, [w:] Szkoła. Wspólnota dążén czy konflikt podmiotów? red. A. Minczakiewicz, A. Szafrańska-Gajdzica, M.J. Szymański, Toruń 2016, s. 101-113; tenże, Znaczenie przywódczej roli wspólnoty w rozwoju jakości pracy szkoły, [w:] Potencjat szkoły w tworzeniu więzi ze środowiskiem, red. I. Nowosad, E. Karmolińska-Jagodzik, Leszno 2013, s. 49-70; tenże, „Bal przebierańców” - różne oblicza (pseudo)wspólnot pokoju nauczycielskiego, [w:] Wyzwania szkolnej codzienności, red. J.M. Łukasik, B. Stankowski, Kraków 2015, s. 15-30; tenże, Klimat pokoju nauczycielskiego, Ruch Pedagogiczny, 2010, 5-6, s. 51-59; tenże, Komunikacja a relacje w gronie nauczycieli. O rzeczywistości "wykorzenionej" z ideatu, Debata Edukacyjna, 2011, 4, s. 54-60.

${ }^{41}$ J. Łukasik, Między szkoła a domem. Role zawodowe i rodzinne nauczycieli, Kraków 2009, s. 116-120.

${ }^{42}$ B. Jakimiuk, Relacje zawodowe i osiagnięcia osobiste jako czynnik satysfakcji z pracy nauczycieli a ich indywidualne doświadczenia, Lublin 2017, s. 230 i n.

${ }^{43}$ Por. J.M. Łukasik, W stronę nauczycielskiej. 
żalski ${ }^{44}$. Z jego badań wynika, że destrukcyjne dla nauczycieli są rywalizacja, brak wsparcia ze strony przełożonych, jak również ze strony współpracowników. Te czynniki wskazują na brak zaufania w miejscu pracy ${ }^{45}$. To relacje interpersonalne utrudniają budowanie kultury zaufania (wyśmiewanie się z innych; przywłaszczanie sukcesów innych - wskazuje na to zjawisko aż 1/3 badanych z populacji 1200 osób; brak życzliwości itp. $)^{46}$. Takie zaś zjawiska, jak mobbing w miejscu pracy ${ }^{47}$ (przejawiający się m.in. $\mathrm{w}$ działaniach ze strony koleżanek, tj.: obgadywanie za plecami, podważanie zdania, złośliwe uwagi i dowcipy; czy ze strony przełożonych: krytykowanie wykonywanej pracy, przy równoczesnym braku wskazówek, jak pracę wykonać; przydzielanie zadań w sposób uniemożliwiający ich realizację; nieudzielanie wsparcia i pomocy $\mathrm{w}$ potrzebie; sprawdzanie pracy nie stosując takich samych standardów wobec innych pracowników; kwestionowanie opinii i pomniejszanie znaczenia opinii w kwestiach, na których się badani znali; uniemożliwianie wypowiedzi; ostentacyjne ignorowanie i lekceważenie ${ }^{48}$ ) nie sprzyjają budowaniu kultury zaufania. Prawidłowe relacje w zespołach badanych nauczycieli najsilniej zakłócają: zazdrość o sukcesy i nagrody; brak szczerej chęci do wsparcia i pomocy ze strony kolegów; rywalizacja; plotkarstwo i intryganctwo, które są również częstą przyczyną konfliktów.

Niski poziom spójności grupowej, brak wyraźnych wartości i norm podzielanych przez nauczycieli, dominująca dezintegracja (rywalizacja, kontrola, nieufność, sankcje, brak więzi, depersonalizacja) oraz osamotnienie nauczycieli wzmacnia brak zaufania (nieufność) i przekłada się na wiele destrukcyjnych zjawisk, a przez to również na niski jakościowy rozwój szkoły.

W uzyskaniu trwałej poprawy potrzebni są przywódcy (formalni bądź nieformalni), którzy pracę nad rozwojem rozpoczną od budowania zaufania. Zaufania, które jak podkreśla Szlendak, rozumiane jest jako

ta wiara w życzliwość i dobro ludzkiej natury - to „cnota krytyczna” (...) Nie ma - niestety - żadnej recepty na budowę kultury zaufania, bo kultura zaufania to rzadkość pośród systemów, w których na świecie żyją ludzie. To unikatowe środowisko społeczne, nie zaś reguła czy norma - udało się takie zbudować nielicznym społeczeństwom. Warto jednak do takiego środowiska dążyć w drodze ku dobremu społeczeństwu ${ }^{49}$.

${ }^{44}$ J. Pyżalski, D. Merecz, Psychospołeczne warunki pracy polskich nauczycieli. Pomiędzy wypaleniem zawodowym a zaangażowaniem, Kraków 2010, s. 47 i n.

45 Tamże, s. 53.

46 Tamże, s. 70.

${ }^{47}$ M. Warszewska-Makuch, Zjawisko mobbingu wśród nauczycieli, Bezpieczeństwo Pracy, 2008,5 .

48 J. Pyżalski, D. Merecz, Psychospołeczne warunki, s. 84 i n.

49 T. Szlendak, Zaufanie, s. 332. 
Optymizmem napawa to, że jako ludzie jesteśmy „istotami urodzonymi do ufności" ${ }^{50}$. Środowisko instytucjonalne może tę skłonność w człowieku osłabić bądź wzmocnić, zawęzić bądź rozszerzyćc ${ }^{51}$. Zatem, od działań podmiotów profesjonalnych, nauczycieli, przywódców, liderów zależy, czy to co tworzą będzie wyznacznikiem budowania zaufania wśród wszystkich podmiotów szkolnej codzienności, czy też podtrzymywaniem nieufności. Zaufanie jako naczelna „,cnota” kultury szkoły oraz lojalność, wzajemność, solidarność, szacunek, sprawiedliwość są podstawą troski i wyznacznikiem rozwoju podmiotów funkcjonujących w jej przestrzeni, jak i samej instytucji.

\section{Konkluzje}

Nader często kultura szkoły jest pomijanym atrybutem procesu zmian. Te podstawowe przekonania i wartości działają jak soczewki dla osób w organizacji do oceny i kształtowania zmian. Dyrektor szkoły, który ma najlepsze intencje odniesie niewielki sukces, jeśli nie będzie w stanie zrozumieć kultury szkoły na jej najgłębszym poziomie - to jedna strona medalu. Druga to umiejętności kształtowania kultury, w tym pozyskania (zachęcenia) ludzi do zmiany swojego zachowania. W obu aspektach pojawia się wiele błędów, które w szkołach skutkują brakiem poprawy, a w efekcie - ograniczaniem szans rozwoju uczniów.

Rick DuFour wskazuje, że postawy członków szkolnej społeczności będą prawdopodobnie ostatnimi, jakie uda się zmienić. Powód jest prosty: przeszłe doświadczenia skutkują obecnymi przekonaniami; wierzenia odzwierciedlają postawy. W zmianie przekonań i postaw konieczne jest zapewnienie możliwości zdobycia nowych, pozytywnych doświadczeń. Dopiero w tym czasochłonnym, żmudnym procesie powstaną nowe lub zmienione przekonania i ostatecznie postawy. To oznacza, że kultura nie może się zmienić, chyba że ludzie zmienią swoje obecne zachowania ${ }^{52}$. Wiele inicjatyw reformatorskich zawodzi, ponieważ kierownictwo nie zajęło się postawami, wartościami podmiotów szkolnej społeczności i tym w co oni wierzą. Elementy te jak w zwierciadle odbijają się w kulturze szkoły. Wystarczy chcieć je odczytać, nauczyć się z nimi pracować i mieć odwagę to zrobić.

50 Tamże.

51 Tamże.

${ }^{52}$ R. DuFour, Schools as learning communities, Educational Leadership, 2004, 61(8), s. 6-11; R. DuFour, R. DuFour, R. Eaker, Revisiting professional learning communities at work: New insights for improving schools, Bloomington 2008; R. DuFour, R. Eaker, R. DuFour (red.), On common ground: The power of professional learning communities, Bloomington 2005. 


\section{BIBLIOGRAFIA}

Angelides P., Ainscow M., Making sense of the role of culture in school improvement, School Effectiveness and School Improvement, 2000, 11(2).

Barber M., Mourshed M., How the World's Best-Performing School Systems Come Out on Top, McKinsey and Co, 2007: ww.mckinsey.com/clientservice/socialsector/resources/pdf/

Belleia C., Vannia X., Valenzuela J.P., Contrerasb D., School improvement trajectories: an empirical typology, School Effectiveness and School Improvement, 2015: https://globaled. gse.harvard.edu/files/geii/files/bellei_et_al_-school_improvement_trajectories.pdf [dostęp: 2017.12.10].

Berends M., A Description of Restructuring in Nationally Nominated Schools. Paper presented at the Annual Meeting of the American Educational Research Association, San Francisco 1992.

Coleman J., Foundations of Social Theory, Harvard University Press, Cambridge - MA - London 1990.

Červinková H., Gołębniak B.D. (red.), Pedagogika i antropologia zaangażowane, Wydawnictwo Naukowe Scholar, Wrocław 2013.

DuFour R., Schools as learning communities, Educational Leadership, 2004, 61(8).

DuFour R., Eaker R., DuFour R. (red.), On common ground: The power of professional learning communities, IN: Solution Tree, Bloomington 2005.

DuFour R., DuFour R., Eaker R., Revisiting professional learning communities at work: New insights for improving schools, IN: Solution Tree, Bloomington 2008.

Fullan M., Change Forces: Probing the Depths of Educational Reform, Falmer Press, London 1993.

Fullan M., Leading in a culture of change, Jossey Bass, San Francisco 2001.

Fullan M., Change forces with a vengeance, Routhledge Falmer, London 2003.

Fullan M., Indelible leadership: Always leave them learning, CA: Corwin Press, Thousand Oaks 2016.

Fullan M., Hargreaves A., Bringing the profession back in: Call to action, OH: Learning Forward, Oxford 2016.

Fullan M., Quinn J., Coherence: The right drivers in action for schools, districts, and systems, CA: Corwin Press, Thousand Oaks 2016.

Gołębniak B.D., Szkoła wspomagająca a rozwój, [w:] Pedagogika. Podręcznik akademicki, tom 2, red. Z. Kwieciński, B. Śliwerski, Wydawnictwo Naukowe PWN, Warszawa 2003.

Gruenert S., Shaping a new school culture, Contemporary Education, 2000, 71(2).

Hannay L.M., Ross J.A., Initiating Secondary School Reform: The Dynamic Relationship between Restructuring, Reculturing, and Retiming, Educational Administration Quarterly, 1997, 33(1).

Hildebrandt A., Koncepcja rozwoju organizacyjnego szkoty Pera Dalina, [w:] Szkice z teorii i praktyki zmiany oświatowej, red. E. Potulicka, Wydawnictwo Eruditus, Poznań 2001.

Hopkins D., Harris A., Stoll L., Macka T., School and System Improvement, State of the Art Review Keynote presentation prepared for the 24th International Congress of School Effectiveness and School Improvement, Limassol 2010, Cyprus, 6th January 2011, w: https:/ / www.icsei.net/icsei2011/State_of_the_art/State_of_the_art_Session_C.pdf [dostęp: 2017.12.10].

Jakimiuk B., Relacje zawodowe i osiagnięcia osobiste jako czynnik satysfakcji z pracy nauczycieli a ich indywidualne doświadczenia, KUL, Lublin 2017.

Kaplan L.S., Owings W.A., Culture Re-Boot: Reinvigorating School Culture to Improve Student Outcomes, Corwin Press 2013, (e-book 2014). 
Leithwood K., Day C., Sammons P., Harris A., Hopkins D., Seven Strong Claims about Successful School Leadership, DfES, London 2006.

Lewin K., Field theory in social science; selected theoretical papers, Harper, New York 1951.

Łukasik J., Między szkota a domem. Role zawodowe $i$ rodzinne nauczycieli, Wydawnictwo AP, Kraków 2009.

Łukasik J.M., Klimat pokoju nauczycielskiego, Ruch Pedagogiczny, 2010, 5-6.

Łukasik J.M., Komunikacja a relacje w gronie nauczycieli. O rzeczywistości "wykorzenionej" z ideatu, Debata Edukacyjna, 2011, 4.

Łukasik J.M., Znaczenie przywódczej roli wspólnoty w rozwoju jakości pracy szkoły, [w:] Potencjał szkoły w tworzeniu więzi ze środowiskiem, red. I. Nowosad, E. Karmolińska-Jagodzik, Wydawnictwo WSH, Leszno 2013.

Łukasik J.M., „Bal przebierańców” - różne oblicza (pseudo)wspólnot pokoju nauczycielskiego, [w:] Wyzwania szkolnej codzienności, red. J.M. Łukasik, B. Stankowski, Wydawnictwo Ignatianum, Wydawnictwo WAM, Kraków 2015.

Łukasik J.M., W stronę nauczycielskiej „wspólnoty wrażliwej” na rozwój, [w:] Szkoła. Wspólnota dążeń czy konflikt podmiotów? red. A. Minczakiewicz, A. Szafrańska-Gajdzica, M.J. Szymański, Wydawnictwo Adam Marszałek, Toruń 2016.

Melosik Z., Systemy ksztatcenia i doskonalenia kadry kierowniczej w krajach Unii Europejskiej i Stanach Zjednoczonych, Ośrodek Rozwoju Edukacji, Warszawa 2014.

Nowak-Dziemianowicz M., Oblicza nauczyciela. Oblicza szkoły, Wydawnictwo Adam Marszałek, Torun 2001.

Nowosad I., Perspektywy rozwoju szkoty. Szkice z teorii szkoty, IBE, Warszawa 2003.

Nowosad I., Uwarunkowania rozwoju szkoły, [w:] Edukacyjne konteksty wspótczesności z myśla o przyszłości, red. J. Madalińska-Michalak, N.G. Pikuła, Oficyna Wydawnicza Impuls, Kraków 2018.

Pyżalski J., Merecz D., Psychospołeczne warunki pracy polskich nauczycieli. Pomiędzy wypaleniem zawodowym a zaangażowaniem, Oficyna Wydawnicza Impuls, Kraków 2010.

Reezigt G.J., Creemers B.P.M. (red.), A framework for effective school improvement. Final report of the ESI project, Groningen Institute for Educational Research, University of Groningen, Groningen 2001.

Rhodes C., Brundrett M., Leadership development and school improvement, Educational Review, 2009, 61(4).

Robinson V., School Leadership and Student Outcomes: Identifying What Works and Why, New South Wales, Australian Council of Leaders, Winmalee 2007.

Stoll L., Fink D., The cruising school: The unidentified ineffective school, [w:] No quick fixes: Perspectives on schools in difficulty, red. L. Stoll, K. Myers, Falmer, London - Washington 1998.

Szlendak T., Zaufanie, [w:] Fundamenty dobrego społeczeństwa. Wartości, red. M. Bogunia-Borowska, Wydawnictwo Znak, Kraków 2015.

Sztompka P., Zaufanie. Fundament społeczeństwa, Wydawnictwo Znak, Kraków 2007.

Sztompka P., Kapitat społeczny. Teoria przestrzeni międzyludzkiej, Wydawnictwo Znak, Kraków 2016.

Waller W., The Sociology of Teaching, Wiley, New York 1932.

Warszewska-Makuch M., Zjawisko mobbingu wśród nauczycieli, Bezpieczeństwo Pracy, 2008, 5.

Yamagishi T., Yamagishi M., Trust and commitment in the United States and Japan, Motivation and Emotion, 1994, 18, 2.

Yashin-Shaw I., Leading in the Innovation Age: Unleash knowledge, talent and experience to create an innovative workplace, BookPod, 2016. 